\title{
Rubeotic glaucoma
}

\author{
REDMOND J. H. SMITH \\ From the Western Ophthalmic Hospital and Moorfields Eye Hospital, City Road, London EC
}

SUMMARY The literature of theories of causation of rubeosis and thrombotic glaucoma is briefly reviewed and attention is drawn to the fact that the causative role of anoxia of the retina, leading secondarily to rubeosis of the iris and subsequent glaucoma, was first described in 1954. After that attempts were made to prevent the rubeosis by means of destruction of large areas of retina, initially by surface diathermy, but subsequently by cryotherapy. Although the visual results of this treatment have proved to be extremely poor, nevertheless none of the 18 eyes involved has had to be enucleated. It is hoped that in the future a judicious combination of better prediction and better treatment should make thrombotic glaucoma a preventable disease.

Glaucoma associated with rubeosis of the iris is one of the most lethal forms of the disease. It usually leads to complete loss of vision and intractable pain, accompanied by bleeding into the anterior chamber. The most common variety is that following occlusion of the central retinal vein, variously called haemorrhagic or thrombotic glaucoma. An identical picture can also follow rubeosis in diabetic retinopathy and in certain cases of long-standing retinal detachment, either simple or secondary to choroidal neoplasia. The condition can also occasionally occur after occlusion of the central retinal artery.

Before 1954, although the relationship between glaucoma and occlusion of the central vein of the retina was recognised, the mechanisms involved were not. Nor had the sequence of events leading to the glaucoma been observed and recorded. Rubeosis itself, in which apparently new vessels ramify on the anterior surface of the iris and in which ectropion of the pigmented pupillary border eventually occurs, had been observed by many workers in 'thrombotic glaucoma' and had been seen in diabetes by Salus ${ }^{1}$ and Kurz, ${ }^{2}$ though François ${ }^{3}$ thought the condition of the iris in diabetes was different from that in central retinal vein occlusion. Rubeosis was also seen in 'cyanosis retinae,' ${ }^{4}$ in Eales's ${ }^{5}$ disease and longstanding retinal detachment, ${ }^{5}$ and in retrolental fibroplasia. ${ }^{6}$ Wagener ${ }^{7}$ described rubeotic glaucoma occasionally occurring after retinal arterial ischaemia and thought it had a similar origin in retinal hypoxia to that of venous rubeosis.

Correspondence to Mr Redmond Smith, 2 Harley Street, London WIN IAA.
The pathology of central retinal vein occlusion had been studied extensively by Verhoeff, ${ }^{8}$ Coats, ${ }^{9}$ and many others. The association of primary glaucoma with central vein occlusion had been pointed out by Foster Moore, ${ }^{10}$ Sugar, $"$ and others, and the formation of new blood vessels on the iris and in the filtration angles had been described. ${ }^{12-14}$ There was, however, no agreement among the various authors about the timing or the role of the neovascularisation, some believing it preceded and others that it followed the glaucoma.

Ashton et al. ${ }^{15}$ clearly showed that retinal ischaemia induced by oxygen overdosage triggering retinal blood vessel closure in the premature eye preceded and probably caused neovascular and fibrous proliferation in the anterior retina and iris. In view of this work Smith ${ }^{16-18}$ carried out a prospective study of cases of central vein occlusion with the object of observing the onset and progress of rubeosis iridis. As a result of this study it was proposed that retinal ischaemia caused the release of a hypothetical metabolite which acted incidentally on the iris, to which it was carried by the circulation of the intraocular fluids, producing neovascularisation on the iris in exactly the same way that it is produced on the retinal surface or on the optic disc in branch vein occlusion or diabetes or in the anterior vitreous as rete mirabile in anterior retinal ischaemic disease or in Eales's disease. (Indeed it is possible that the same principle may extend to the pathology of disciform degeneration of the retina, so that the preliminary detachment of the central retina with or without the pigment epithelium may produce enough hypoxia in 
the detached receptors to invoke a subretinal neovascular response from the underlying choroidretroretinal rubeosis.)

The pathological principles involved in this sequence, which are of crucial importance, are thus as follows: first, chronic ischaemia and hypoxia of the retina leads to the release of a neovascularising factor; secondly, the factor, which is probably a diffusible chemical substance, can be transported to various sites in the eye by the intraocular fluids; thirdly, the resultant new vessels lie in a matrix which includes or induces fibrous tissue which eventually cause adhesions and contractions (peripheral synechiae and ectropion uveae in the iris and retinitis proliferans in the retina); and, fourthly, the new vessels may bleed.

Thus this fundamental pathological process, first clearly identified in retinopathy of prematurity by Ashton et al. ${ }^{15}$ lies at the basis of at least 3 major ophthalmic diseases, namely, retrolental fibroplasia, diabetic retinopathy, and thrombotic glaucoma, with disciform macular degeneration (retroretinal rubeosis) as a possible fourth.

Where the understanding of a pathological sequence is attained, the next step is for some form of treatment to be devised to try to modify or prevent it. In the case of retrolental fibroplasia the initial avascularity of the retina caused by oxygen overdosage was prevented by suitable modifications of oxygen therapy in premature infants. In the case of rubeotic glaucoma due to central vein occlusion no action was taken for some years after the publications of 1954, but in January 1960 an attempt at fundamental treatment was started. ${ }^{19}$

\section{Materials and methods}

Between January 1960 and September 19669 eyes (of 8 patients) were treated by anterior retinal diathermy. The technique involved applications of surface diathermy in a band 14 to $16 \mathrm{~mm}$ from the limbus at 70 milliamps for 5 seconds. Subsequent monitoring was carried out where visibility allowed and adequate retinal destruction was seen.

\section{Results}

The results are summarised in Table 1 . It can be seen that only 1 patient retained good vision, the first patient, and another retained 6/36. Otherwise, visual results were very poor, but rubeosis was inhibited or abolished in 5 of the 9 eyes, and the final intraocular pressures were normal in 5 eyes. Persistent uveitis occurred in all the eyes with flare and cells in the aqueous humour.

With the advent of cryotherapy it was decided to abandon surface diathermy in favour of cryoablation of the retina in the hope that the lesser uveal and virtually absent surface damage would reduce postoperative uveitis. From May 1966 until April 1979 a further 9 eyes of 9 patients were treated by cryoablation. The earlier cases were treated by cryoablation by choice, but in some other later cases cryoablation was used as an alternative to panphoto-

Table 1 Anterior retinal diathermy

\begin{tabular}{|c|c|c|c|c|c|c|c|c|c|}
\hline \multirow{2}{*}{$\begin{array}{l}\text { Date } \\
\text { first seen }\end{array}$} & \multirow{2}{*}{$\begin{array}{l}\text { Hosp. no. } \\
\text { File no. }\end{array}$} & \multirow[t]{2}{*}{ Sex/Age } & \multirow[t]{2}{*}{ Eye } & \multirow[t]{2}{*}{ Brief history } & \multirow[t]{2}{*}{ Follow-up } & \multicolumn{4}{|l|}{ Final state } \\
\hline & & & & & & Rubeosis & Pain & $I O P$ & $V A$ \\
\hline 1 June 59 & $\begin{array}{l}595739 \\
21\end{array}$ & $\mathbf{M} / 53$ & $\begin{array}{l}\mathbf{L} \\
\mathbf{R}\end{array}$ & $\begin{array}{l}\text { Bilateral CRVO with rubeosis and corneal } \\
\text { oedema. ARD } 360^{\circ} \text { both eyes L-Jan } 60 \text {, } \\
\text { R-Mar } 60\end{array}$ & $\begin{array}{l}18 \mathrm{mo} \\
18 \mathrm{mo}\end{array}$ & $\begin{array}{l}\text { Reduced } \\
\text { Not improved }\end{array}$ & 0 & 15 & $6 / 9$ \\
\hline 31 Dec. 59 & $\begin{array}{l}002237 \\
23\end{array}$ & $\mathbf{M} / 72$ & $\mathbf{L}$ & $\begin{array}{l}\text { CRVO plus open angle glaucoma. Rubeosis } \\
\text { began after } 4 \text { mo. ARD } 360^{\circ} \text {. Had diabetic } \\
\text { coma aged } 93 \text {. Still alive } 1980\end{array}$ & $21 \mathrm{yr}$ & Abolished & 0 & 20 & $\mathrm{CF}$ \\
\hline 3 Aug. 60 & $\begin{array}{l}607031 \\
24\end{array}$ & $\mathbf{M} / 80$ & $\mathbf{R}$ & $\begin{array}{l}\text { CRVO with pupillary and trabecular } \\
\text { rubeosis. ARD } 360^{\circ}\end{array}$ & $8 \mathrm{mo}$ & 'almost nil' & 0 & 23 & $6 / 36$ \\
\hline 1960 & $\begin{array}{l}\text { Private } \\
\text { patient } \\
22\end{array}$ & $\mathrm{M} / 70$ & - & $\begin{array}{l}\text { Established thrombotic glaucoma. } \\
360^{\circ} \text { ARD }\end{array}$ & & Not improved & & & \\
\hline 22 Aug. 60 & $\begin{array}{l}556825 \\
25\end{array}$ & $\mathrm{M} / 54$ & $\mathbf{L}$ & $\begin{array}{l}\text { Thrombotic glaucoma with trabecular } \\
\text { rubeosis, but no PAS. ARD } 360^{\circ}\end{array}$ & $6 \mathrm{mo}$ & Nil & 0 & 18 & $4 / 60$ \\
\hline Feb. 63 & $\begin{array}{l}\text { D51138 } \\
58\end{array}$ & $F / 67$ & $\mathbf{L}$ & $\begin{array}{l}\text { CRVO_glaucoma after } 3 \text { mo with } \\
\text { trabecular rubeosis. ARD } 360^{\circ}\end{array}$ & $2 \frac{1}{2} \mathrm{yr}$ & Nil & 0 & 9 & CF \\
\hline 1965 & $\begin{array}{l}\text { D53882 } \\
84\end{array}$ & $F / 73$ & $\mathrm{~L}$ & Diabetic rubeosis. IOP 53. ARD $360^{\circ}$ & $6 \mathrm{mo}$ & Still present & & 60 & No PL \\
\hline 1966 & $\begin{array}{l}\text { C56699 } \\
88\end{array}$ & $\mathbf{M} / 37$ & $\mathbf{R}$ & $\begin{array}{l}\text { Diabetic with rubeosis. ARD } 360^{\circ} \text { plus } \\
3 \times \text { cyclo-diathermies }\end{array}$ & $9 \mathrm{mo}$ & Improved & 0 & 26 & PL \\
\hline
\end{tabular}

$\overline{\mathrm{CRVO}}=$ central retinal vein occlusion. $\mathrm{ARD}=$ anterior retinal diathermy. $\mathrm{IOP}=$ intraocular pressure. $\mathrm{CF}=$ counting fingers. $\mathrm{PL}=$ perception of light. $\mathrm{NPL}=$ no perception of light. 
Table 2 Cryoablation

\begin{tabular}{|c|c|c|c|c|c|c|c|c|c|}
\hline \multirow{2}{*}{$\begin{array}{l}\text { Date } \\
\text { first seen }\end{array}$} & \multirow{2}{*}{$\begin{array}{l}\text { Hosp. no. } \\
\text { File no. }\end{array}$} & \multirow[t]{2}{*}{ Sex/Age } & \multirow[t]{2}{*}{ Eye } & \multirow[t]{2}{*}{ Brief history } & \multirow[t]{2}{*}{ Follow-up } & \multicolumn{4}{|l|}{ Final state } \\
\hline & & & & & & Rubeosis & Pain & $I O P$ & $V A$ \\
\hline 4 May 66 & $\begin{array}{l}664008 \\
90\end{array}$ & $\mathbf{M} / 50$ & $\mathbf{L}$ & $\begin{array}{l}\text { CRVO with early rubeosis of iris. } \\
\text { Cryoablation and repeat cyclodiathermy }\end{array}$ & $7 \mathrm{yr}$ & Not abolished & 0 & 30 & NPL \\
\hline $\begin{array}{l}3 \text { Mar. } 64 \\
\text { (photo) }\end{array}$ & $\begin{array}{l}000348 \\
101\end{array}$ & $\mathrm{M} / 56$ & $\mathbf{R}$ & $\begin{array}{l}\text { CRVO in open angle glaucoma rubeosis of } \\
\text { iris and angle } 1971 \text {. Retinal cryoablation }\end{array}$ & $9 \mathrm{yr}$ & Not abolished & 0 & 31 & NPL \\
\hline $\begin{array}{l}27 \text { Mar. } 72 \\
\text { (iris photo) }\end{array}$ & $\begin{array}{l}\text { D63402 } \\
108\end{array}$ & $F / 47$ & $\mathbf{L}$ & $\begin{array}{l}\text { CRVO with thrombotic glaucoma. IOP } \\
70 \mathrm{mmHg} \text { and corneal oedema. } 360^{\circ} \text { retinal } \\
\text { cryoablation }\end{array}$ & $71 / 2 \mathrm{yr}$ & Abolished & 0 & 18 & CF \\
\hline 16 Nov. 72 & $\begin{array}{l}\text { D64206 } \\
108\end{array}$ & $\mathbf{F} / 60$ & $\mathbf{L}$ & $\begin{array}{l}\text { CRVO with thrombotic glaucoma. IOP } \\
80 \mathrm{mmHg} .360^{\circ} \text { cryoablation }\end{array}$ & $5 \mathrm{yr}$ & Abolished & 0 & 16 & NPL \\
\hline 23 Aug. 73 & $\begin{array}{l}\text { D65165 } \\
108\end{array}$ & $\mathrm{M} / 68$ & $\mathbf{L}$ & $\begin{array}{l}\text { CRVO with chronic open angle glaucoma. } \\
\text { Rubeosis developing. Iris angiography. } \\
360^{\circ} \text { cryoablation }\end{array}$ & $3 \mathrm{yr}$ & No change & 0 & 20 & NPL \\
\hline 20 Aug. 74 & $\begin{array}{l}\text { D66461 } \\
108\end{array}$ & $\mathbf{M} / 75$ & $\mathbf{L}$ & $\begin{array}{l}\text { CRVO with thrombotic glaucoma. Extensive } \\
\text { angle closure and rubeosis. } 360^{\circ} \text { cryoablation }\end{array}$ & $3 \mathrm{yr}$ & Cured & 0 & 20 & PL \\
\hline 3 Mar. 75 & $\begin{array}{l}\text { D67008 } \\
108\end{array}$ & $\mathrm{~F} / 71$ & $\mathrm{~L}$ & $\begin{array}{l}\text { Old CRVO-disc vessels and rubeosis. } \\
\text { IOP } 50 \mathrm{mmHg} \text {. Peripheral anterior synechiae: } \\
\text { 40\%. 10.3.75: 'peripheral retinal cryoablation' }\end{array}$ & $5 \mathrm{yr}$ & Nil & 0 & 20 & NPL \\
\hline 7 July 78 & $\begin{array}{l}054355 \\
108\end{array}$ & $\mathbf{M} / 53$ & $\mathbf{L}$ & $\begin{array}{l}\text { Established thrombotic glaucoma. IOP } \\
40 \mathrm{mmHg} \text {. Laser followed by } 360^{\circ} \text { retinal } \\
\text { cryotherapy plus cyclo cryotherapy }\end{array}$ & $1 \mathrm{yr}$ & Regression & 0 & 26 & NPL \\
\hline 17 Apr. 79 & $\begin{array}{l}058177 \\
108\end{array}$ & $\mathbf{M} / 75$ & $\mathbf{R}$ & $\begin{array}{l}\text { Diabetic with thrombotic glaucoma. IOP } \\
60 \mathrm{mmHg} \text {. Angle flush plus small hyphaema. } \\
360^{\circ} \text { cryoablation. Later repeated }\end{array}$ & $1 \mathrm{yr}$ & Failure & + & 28 & NPL \\
\hline
\end{tabular}

Abbreviations as in Table 1.

coagulation because of opacities in the media. One case was treated by both laser therapy and cryoablation. The technique consisted in applying cryotherapy to the entire pre-equatorial retina, and retinal destruction was monitored by ophthalmoscopy where possible.

The visual results in this series were rather worse than in the previous group, 7 of the 9 eyes ending with no perception of light, 1 with only hand movements, and another with counting fingers. Intraocular pressures were improved in most; however, rubeosis was reduced in 1 and abolished in 4 , and only 1 eye remained painful.

\section{Discussion}

One hopes that the poor visual results in these 2 groups of eyes can be attributed to the retinal vascular disease. Although it is possible that the retinal ablation did enough damage to contribute to the poor visual prognosis, without cryoablation a proportion of the eyes would have progressed to the gross form of rubeotic glaucoma with intractable pain, necessitating enucleation. Indeed in Laatikinen and Kohner's 1976 series $^{20} 17 \cdot 7 \%$ of such eyes developed thrombotic glaucoma.

It is claimed, therefore, that the diathermy or the cryoablation of extensive areas of retina reduced the extent of the ischaemic retina to such a degree that the production of the neovascularising factor fell below the threshold for iris neovascularisation and that this resulted in regression of the rubeosis.

These early attempts at treatment must, however, be considered crude and somewhat indiscriminate. Rather than waiting for rubeosis to start, by which time extensive vasoformative membranes would have been formed, far more extensive than the visible rubeosis, it would be preferable to be able to select accurately those cases which were likely to suffer from rubeosis and treat them only.

Laatikinen and Kohner ${ }^{20}$ showed that fluorescein angiographic evidence of extensive capillary closure following retinal vein occlusion was always followed by rubeotic glaucoma. Laatikinen ${ }^{21}$ in a preliminary report of 8 cases of vein occlusion, 1 of arterial occlusion with rubeosis, and 1 of diabetes with rubeosis, carried out panphotocoagualation and found virtually identical results to those presented in this paper. Her results are confirmed in a larger study ${ }^{22}$ in which a randomised clinical trial was carried out with controls, and similar results have been reported in retinal cryoablation by May and others. ${ }^{23}$

In summary, therefore, the position at this stage appears to be as follows. The available evidence supports the theory that retinal hypoxia induces rubeosis iridis by means of a diffusible substance, as first proposed in 1954 . The ability to predict rubeosis has been enormously improved by the fluorescein 
angiographic techniques which have become available. Early attempts at treatment by diathermy or cryotherapy saved vision in only a very few eyes, but the eyes themselves were saved. Later, photocoagulation with the benefit of fluorescein angiographic knowledge produced approximately similar results clinically, namely, very little visual salvage but no loss of eyes.

The next stage in these studies therefore appears to be to consolidate the earlier work and to confirm the absolute necessity of early panretinal ablation where fluorescein studies suggest the likelihood of rubeotic glaucoma.

\section{References}

1 Salus R. Rubeosis diabetica, eine bisher unbekannte diabetische Irisveranderung. Med Klin 1928; 7:256-8.

2 Kurz O. Zur Rubeosis Iridis diabetica. Arch Augenheilkd 1937; 110: 284-302.

3 François J. La rubeose de l'iris. Ophthalmologica 1951; 121: 313-33.

4 Kyle JL. Ocular findings in congenital heart disease. Can Med Assoc J 1950; 62: 263-6.

5 Zollinger R. Uber das Vorkommen von Gefassneubildung auf der Iris. Ophthalmologica 1951; 121: 168-72.

6 Ashton N. Pathological basis of retrolental fibroplasia. $\mathrm{Br} J$ Ophthalmol 1954; 38: 385-96.

7 Wagener HD. Glaucoma following occlusion of the central retinal artery. JAMA 1960; 240: 253-64.

8 Verhoeff F. Obstruction of the central retinal vein. Arch Ophthalmol 1907; 36: 1-36.
9 Coats G. Discussion on retinal vascular disease; pathological aspects. Trans Ophthalmol Soc UK 1913. 33: 30-7.

10 Moore RF. Retinal venous thrombosis: a clinical study of 62 cases followed over many years. Br J Ophthalmol 1924; monog suppl 2.

11 Sugar HS. Place of haemorrhagic glaucoma in etiologic classification of glaucoma. Arch Ophthalmol 1942; 28: 587-98.

12 Samuels B. Pathologic changes in the anterior half of the globe in obstruction in the central vein of the retina. Trans Am Ophthalmol Soc 1932; 32: 369-88.

13 Holm E. Peripupillary web of vessels in haemorrhagic glaucoma. Acta Ophthalmol (Kbh) 1945; 23: 343-52.

14 Braendstrup P. Central retinal vein thrombosis and haemorrhagic glaucoma. Acta Ophthalmol (Kbh) 1950; suppl 35.

15 Ashton N. Ward B. Serpell G. Effect of oxygen on developing retinal vessels with particular reference to the problem of retrolental fibroplasia. Br J Ophthalmol 1954; 38: 397-432.

16 Smith RJH. Thrombotic glaucoma. a clinico-pathological study. Acta Concilium Ophthalmologicum 1954; 17: 1164-75.

17 Smith RJH. Concerning glaucoma and retinal venous occlusion. Trans Ophthalmol Soc UK 1955: 75: 265-79.

18 Smith RJH. Observations on the normal anatomv of certain ocular vessels and on glaucoma associated with occlusion of the central retinal vein. Thesis for MS degree. London University. 1956.

19 Smith RJH. Neovascularisation in ocular disease. Trans Ophthalmol Soc UK 1961: 81: 125-44.

20 Laatikinen L. Kohner EM. Fluorescein angiography and its prognostic significance in central retinal vein occlusion. $\mathrm{Br} J$ Ophthalmol 1976; 60: 411-8.

21 Laatikinen L. Preliminary report on effect of retinal panphotocoagulation on rubeosis iridis and neovascular glaucoma. $\mathrm{Br} J$ Ophthalmol 1977: 61: 278-84.

22 Laatikinen L. Kohner EM. Khoury D. Blach RK. Panretinal photocoagulation in central retinal vein occlusion: a randomised controlled clinical study. Br J Ophthalmol 1977: 61: 741-53.

23 May DR. Bergstrom TJ. Parmet AJ. Schwartz JG. Treatment of neovascular glaucoma with transcleral panretinal cryotherapy. Ophthalmologv 1980; 87: 1106-11. 